Dicle University Journal of Engineering (DUJE)

web: http://dergipark.gov.tr/dumf

Araștırma Makalesi / Research Article

\title{
Bazalt Agregalı Bitümlü Sıcak Karışım Tabakalarının Dinamik Rijitlik Modülünün Hesaplanması ve Marshall Tasarım Kriterleriyle Karşılaştırılması
}

\section{Determination of Dynamic Stiffness Module of Basalt Aggregated Bituminous Hot Mix Layers and Comparison with Marshall Design Criteria}

\author{
İhsan Güzel ${ }^{1 *}$, Ahmet Benli² \\ ${ }^{1}$ Bingöl Üniversitesi, İnşaat Mühendisliği Bölümü, Bingöl, iguzel@bingol.edu.tr \\ ${ }^{2}$ Bingöl Üniversitesi, İnşaat Mühendisliği Bölümü, Bingöl, abenli@bingol.edu.tr
}

\begin{tabular}{l} 
MAKALE BİLGİLERİ \\
\hline Makale geçmişi: \\
Geliş: 31 Mart 2020 \\
Düzeltme: 5 Eylül 2020 \\
Kabul: 10 Eylül 2020 \\
\hline Anahtar kelimeler: \\
Tasarım,Dinamik Rijitlik Modülü, \\
Asfalt Betonu,Marshall Dizaynı \\
,Master ,Eğrisi
\end{tabular}

\begin{abstract}
ÖZET
Ülkemizde 2008 yılında yayınlanan Esnek Üstyapılar Projelendirme Rehberiyle, tasarımcıya çeşitli tasarım ve malzeme seçiminde olanaklar sağlayan, ampirik ve analitik yönteme dayalı AASHTO (American Association of State Highway and Transportation Officials) 2002 Esnek Üstyapı Projelendirme Rehberi kriterlerine geçiş yapılmaya başlanmıştır. AASHTO 2002 Projelendirme Rehberinde, kaplama performansını etkileyen en önemli faktörlerden olan dinamik rijitlik modülü ikinci, üçüncü hiyerarşik seviye projeler için deney yapılmadan tahmin modelleriyle hesaplanmasına izin verilmektedir. Tahmini modellerle hesaplanan dinamik rijitlik modülünün, ülkemizde bitümlü sıcak karışım dizaynında yaygın olarak kullanılan Marshall yöntemi verileriyle ilişkisinin araştırılması proje bazında tasarımcıya alternatif olanaklar sağlayacaktır. Bu çalışmada bazalt agregalı bitümlü temel, binder ve așınma tabakalarının karıșım tasarımları Marshall yöntemiyle yapılarak; belirlenen frekans ve sıcaklıklarda optimum bitüme göre Witczak 2002 Modeliyle dinamik rijitlik modülleri hesaplanıp ana eğrileri çizilmiştir. Sonuç olarak dizayn kriter değerlerinde maksimum dinamik rijitlik modülüne yaklaşılmış ve sıcaklığın yükleme sürelerine göre dinamik rijitlik modolünü daha fazla etkilediğinden projelerde öncelikli olarak iklim şartlarına göre tabakaların dinamik rijitlik modülünün belirlenerek tasarım yapılması, ayrıca aşınma karışımlarının dayanımın artırılması içimn maksimum agrega tane boyutunun büyütülmesi gerektiği tespit edilmiștir.
\end{abstract}

\begin{tabular}{l} 
ARTICLE INFO \\
\hline Article history: \\
Received: 31 March 2020 \\
Revised: 5 September 2020 \\
Accepted: 10 September 2020 \\
\hline Keywords: \\
Design,,Dynamic,Stiffness \\
Module, Asphalt Concrete, \\
Marshall Design, Master Curve
\end{tabular}

* Sorumlu yazar / Correspondence Ahmet BENLI

$\triangle$ abenli@bingol.edu.tr

\begin{abstract}
In Turkey with the published Flexible Pavements Projecting Guide 2008, the designer that offer opportunities in various design and material selection, empirical and analytical methods based on AASHTO (American Association of State Highway and Transportation Officials) 2002 Flexible Pavement Design Guide is being made the transition to the criteria. In AASHTO 2002 Project Designing Guide, dynamic stiffness module, which is one of the most important factors affecting coating performance, is allowed to be calculated with estimation models for second and third hierarchical level projects. Investigating the relationship between the dynamic stiffness module calculated with estimated models and Marshall method data, which is widely used in bituminous hot mix design in our country, will provide alternative opportunities for the designer on a project basis. In this study, the mixture designs of basalt aggregate bituminous foundation, binder and wear layers are made by Marshall method; According to the optimum bitumen at determined frequencies and temperatures, dynamic stiffness modules are calculated with Witczak 2002 Model and their main curves are drawn. As a result, it has been determined that the maximum dynamic stiffness modulus in design criteria values has been approached and since the temperature affects the dynamic stiffness modulus more than the loading times, it has been determined that the dynamic stiffness modulus of the layers should be determined primarily in the projects according to the climatic conditions, and the maximum aggregate particle size should be increased in order to increase the strength of the wear mixtures.
\end{abstract}




\section{Giriș}

Ülkemizin, karayolu uzunlukları karşılaştırılmasında uluslararası kıstas olan karayolu uzunluğunun ülke yüzölçümü oranı, gelişmiş ülkelere göre daha düşük olması nedniyle ihtiyaç olan karayolu kaplamalarının esnek kaplamadan elde edilen deneyimler ve bu kaplamaların avantajları dikkate alınarak esnek kaplama tipinin tercih edilebilecektir. Ayrıca mevcut asfalt betonu yol kaplamalarının bakım ve onarımında asfalt betonunun kullanımı öncelikli olacaktır. Bu nedenle esnek üst yapıların proje şartlarını daha fazla göz önünde bulunduran yöntenle tasarlanması sürdürülebilirlik açısından önemlidir.

Asfalt betonu üst yapısının tasarımı amprik, analitik, amirik - analitik yöntemlerle yapılmaktadır. AASHTO 1972 rehberi, CBR (California Bearing Ratio) yöntemi amprik yöntemlere, AASHTO 1986, AASHTO 1993 rehberleri ve bu rehberlere göre daha detaylı ve değişik girdilerin girilmesine olanak sağlayan AASHTO 2002 rehberi amprik - analitik yöntemlere, Shell yöntemi ise analitik yöntemlere örnek olarak verilebilir.[1]

Tasarımcıya çeşitli tasarım ve malzeme seçiminde olanaklar sağlayan AASHTO 2002 rehberi, AASHTO'nun diğer rehberlerinin eksiklik ve yetersizlliklerini (Trafik yükü, tabakalarda kullanılan malzeme özellikleri, gerçeği temsil edecek iklim ve çevre koşulları vb) [2], proje özelliği ve mevcut imkanlara göre tasarımcıya üç seviyede girdi girilmesini sağlayarak minimize etmektedir.

AASHTO 2002 Rehberinde üst yapı tasarımını ve performansını doğrudan kullanılan; kalibrasyon faktörleri, kaplama tabakalarının birim şekil değiştirmesi, deformasyonu ve karışımların en temel özelliği olan dinamik rijitlik modülü etkilemektedir. Dinamik rijitlik modülü birinci seviye için deneysel, ikinci ve üçüncü seviyeler için ise yaklaşık yöntemlerle hesaplanmaktadır [3]

Amprik - analitik yönteme geçiş yapılmak üzere AASHTO 1993 kriterleri esas alınarak 2008 yılında yayınlanan ve halen yürürlükte olan Karayolları Esnek Üstyapı Projelendirme Rehberin'de asfalt betonu kaplamaların kalınlığı eşdeğer standart dingil yükü sayısı, güvenilirlik, üstyapı taban zemini esneklik modülü, çevre ve iklim koşullarına göre belirlenmektedir $\mathrm{Bu}$ rehberde yeni yapılacak üstyap1 ve takviye tabakalarının kalınlıklarının belirlenmesinde kullanılan üst yapı sayısı malzemelerin için belirlenen izafi mukavemet katsayılarına göre hesaplanmakta olup; aşınma ve binder kaplama tabakalarının toplam kalınlığ $11 \mathrm{~cm}$ ile $18 \mathrm{~cm}$, bitümlü temel tabakası kalınlığ $8 \mathrm{~cm}$ ile $16 \mathrm{~cm}$, plentmiks temel 15 ile $20 \mathrm{~cm}$, alttemel tabakas1 kalınlığı ise 0 ile $50 \mathrm{~cm}$ arasında değişmektedir [4].

2019 yılı fiyatlarına göre ocak taşından aşınma, binder, bitümlü temel tabakalarının bir santim kalınlığının ortalama maliyeti $5 \mathrm{TL} / \mathrm{m}^{2}$, olup; \% 50'si bitüm zati bedelidir. Plentmiks temel ve plentmiks alt temel tabakalarının bir santim kalınlığının yaklaşık maliyeti ise $1 \mathrm{TL} / \mathrm{m}^{2} \mathrm{dir}$ [5].

Yeni yapılacak karayolu üst yapıları ve mevcut üstyapıların onarım maliyetleri göz önüne alındığında; iklim, çevre ve trafik yükü koşullarında, proje süresince asfalt betonu kaplamalarının hedeflenen performans1 karşılaması ülke ekonomisi açısından önemlidir. Üst yapılarda hedef performansin gerçekleşmesini önemli seviyede AASHTO 2002 'de belirtildiği üzere ülke koşullarına uygun kalibrasyon faktörleriyle beraber tabakaların en temel özelliği olan dinamik rijitlik modülüün, kullanılan malzemelere göre belirlenmesi etkilemektedir.

Ülkemizde yürürlüte olan üst yap1 projelendirme rehberinde tasarım;karışım malzemelerinin farklılıklarını dikkate almadan genel olarak belirlenen dinamik riuitlik modülüyle ilişkili olan tabakaların izafi mukavemet katsayılarıyla yapılmaktadır. Proje bazında temin edilebilecek agrega türlerine göre tabaka tasarım yapılması üst yap1 performans1 için önemlidir.

$\mathrm{Bu}$ nedenle aynı ocaktan üretilen bazalt agregalı bitümlü temel, binder ve aşınma tabakalarının, ülkemizde süper pave dizaynına geçinceye kadar kullanılacak Marshall dizaynı verileriyle, AASHTO 2002 Rehberin'de ikinci, üçüncü hiyerarşik seviye projelerde tahminine izin verilen dinamik rijitlik modül ilişkisinin incelenmesinin, proje bazında tasarımcılara ekonomik degerlendirmelere ve analitik 
çalışmalara katkıda bulunacağı düşünülerek bu çalışma yapılmıştır.

\section{Üstyapı Tabakalarının Esneklik ve Dinamik Rijitlik Modülü}

Karayolu esnek üstyapılarını amprik ve analitik yöntemle tasarlanması için tabakalara elastik teorinin uygulaması gerekmektedir. Bu durumda tabakaların statik yük yerine gerçek yükleme koşullarına uygun olan tekrar eden yükler altında elastikiyet modülü Şekil-1 'de görüleceği üzere tekerrür eden yüklerle yapılan üç eksenli deneylerde elde edilen devilatör gerilmenin elastik deformasyona oranı olan esneklik; (resilient) modülü ile yaklaşımıyla yapılmaktadır [6].

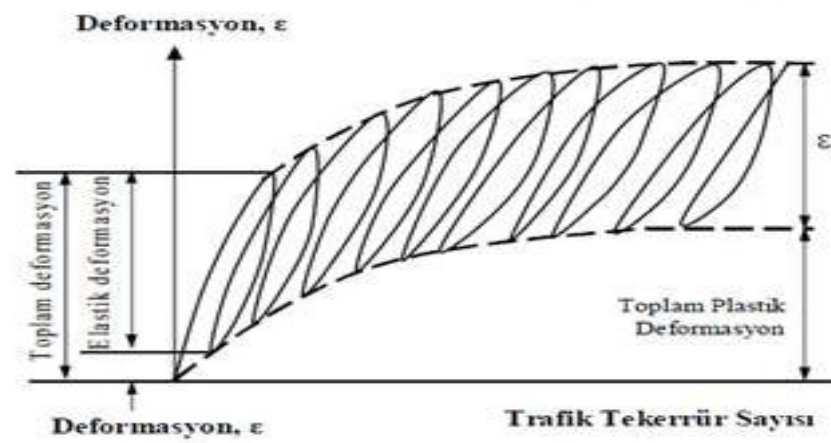

Şekil 1. Üstyapı malzemelerinin tekrarlı yükdeformasyon ilişikisi[6]

Karayolları Genel Müdürlüğü'nün yürürlükte olan Esnek Üstyap1 Projelendirme Rehberin'de alttemel, temel ve üstyapı tabanının esneklik modülü, asfalt betonu kalınlığ $1, \mathrm{CBR}$,optimum rutubet,maksimum kuru birim ağırlık, likit limit, ,plastisite indeksi, derinlik düzeltme faktörü,No4 ve No200 'den geçen malzeme yüzdeleriyle ilişkilidir.Rehberde belirtilen izafi mukavemet katsayılarına göre çimento bağlayıcılı granüller temel 133520 psi (921MPa) ,plentmiks temel granüler temel 37037 psi(256MPa), granüler temel 30112 psi (208MPa), kırma taş alttemel 24110 psi (166MPa),kum çakıl alttemelin ise 14606 psi (101 MPa) olarak esneklik modüllerinin kabul edildiği hesaplamalarla tespit edilmiştir.

Bitümlü karışımların serilip sıkıştırıldıktan sonra tabakada oluşan boşluklar tabakanın mekanik ve fiziksel özelliklerini etkilerken; vizkoelastik ve termoplasttık malzeme olan bitüm sıcaklık ve trafik yüklemelerine bağlı olarak sıkıştırılmış kaplamada, reolojik hali nedeniyle en büyük etkiyi yapmaktadır.

Bitümlü karışım tabakalarının performansının değerlendirilmesinde gözönüne alınan mekanik özelliklerden birisi olan rijitlik, bitünlü karışım malzemelerin vizkoelastik malzeme olması nedeniyle elastik malzemelerin elastikiyet modülüne benzeyen yükleme hızı, yükleme süresi ve sicaklık dikkate alınarak gerilme defermasyon arasındaki ilişkiyi ifade eden rijitlik modülü ile tanımlanmaktır. Rijitlik modülü indirekt çekme, sünme, üç eksenli tekerrürlü yük, üç eksenli dinamik modül, serbest basınç veya çekme deneyleriyle tespit edilmekle beraber, bitüm rijitliği, karışımdaki agrega ve bitümün hacimsel yüzdeleri, akma, stabilite ve serbest basınç mukavemet değişkenleri dikkate alınarak Nijboer,GoetMetcalf,Henkelom-Klomp yaklaşımı, Shell Abakları ve Bonnaune'nin geliştirdiği eşitliklerle de hesaplanmaktadır [7].

Trafik yükünün en fazla etkili olduğu asfalt betonu kaplama (aşınma, binder) karışım numunelerine uygulanan tekerrürlü maksimum yükün yatay yönde kaydedilen birim şekil değiştirme oranı olarak tanımlanabilen esneklik modülü [8],tabakaların yük dagıtma kabiliyetinin bir göstergesi olmasına rağmen viskoelastik karışımların mekanik özelliklerini tam olarak temsil etmemektedir.

Viskoz davranış gösteren asfalt betonu karışımların performansını değerlendirmek için Papazian tarafından 1962 yılında yapılan çalışmalarda kompleks modülü kavramı belirtilmiştir[9]. 1970 yılının başında bu kavram Asfalt Enstitüsü tarafından kullanılmıştır [10] .

Doğrusal viskoelastik malzemelerin sürekli bir sinüzoidal yükleme altında meydana gelen Şekil 2'de gösterilen gerilme, şekil değiştirme genlikleriyle ilişkilendiren tekerlek izi ve yorulma çatlaklarının öngörülmesini sağlayan kompleks modülün (Eşitlik-1) mutlak değeri genellikle dinamik modül olarak adlandırılır. Asfalt karışımların rijitliğinin zaman ve sıcaklıkla ilişkili detaylı olarak hesaplanması olarakta tanımlanan dinamik modülün artması 
asfatt betonu tabakasının trafik yüklemeleri altında deformasyonlara ve yüksek sıcaklıklarda teker izine karsı direncini ve düşük 1sı çatlaklarına duyarlığını artıracaktır [11].

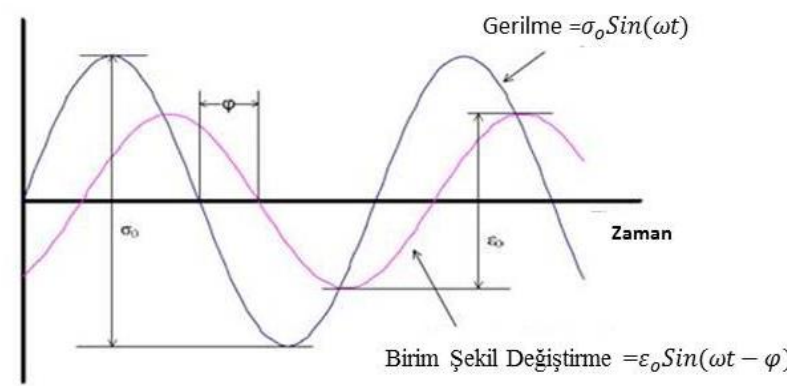

Şekil 2. Dinamik kompleks modülü testinin şematik bileşenleri[11]

$E^{*}=\frac{\sigma_{o} \operatorname{Sin}(\omega t)}{\varepsilon_{0}-\operatorname{Sin}(\omega t-\varphi)}$

$\omega=2 . \pi . f$

$\varphi=\frac{t_{\text {lag }}}{t_{p}} \cdot\left(360^{\circ}=t_{\text {lag }} \cdot f \cdot\left(360^{\circ}\right)\right.$

$\mathrm{E}^{*}$ kompleks modül, $\sigma_{o}$ tepe gerilme, $\varepsilon_{o}$ tepe birim şekil değiştirme, $t$ zaman, $\omega$ açısal hız, $\varphi$ tepe gerilme ile tepe birim şekil defermasyon arasındaki zaman fark1 (Faz acısı) $t_{p}$ tekrarlı gerilmenin yükleme periyodu, $t_{\text {lag }}$ gerilme şekil değiştirme arasında zaman farkıdır.

AASHTO 2002 Rehberin'de hiyerarşik olarak birinci seviye projelerde farklı frekans $(25,10$, $5,1.0,0.5,0.1 \mathrm{~Hz})$ ve sicakliklarda $((-10,4.4$, $\left.21.1,37.8,54.4^{\circ} \mathrm{C}\right)$ elde edilen dinamik modülü deney sonuç eğrileri zaman ve sicaklık süperpozisyon ilkesine gore referans sıcaklığ referans alınarak tek bir düz fonksiyonda birleşene kadar yükleme süresinde değişim yapılarak (Eşitlik 2,3) meydana getirilen dinamik modül master (ana) eğrisinden zamana (frekans) bağlı dinamik modül değerleri hesaplanmaktadır (Şekil 3,4).Maryland Üniversitesi tarafından yapılan araştırmalarda dinamik modül master eğrisinin Eşitlik-4'de gösterilen sigmimodal fonksiyonla (Şekil-5) temsil edileceği gösterilmiştir $[12,13]$.

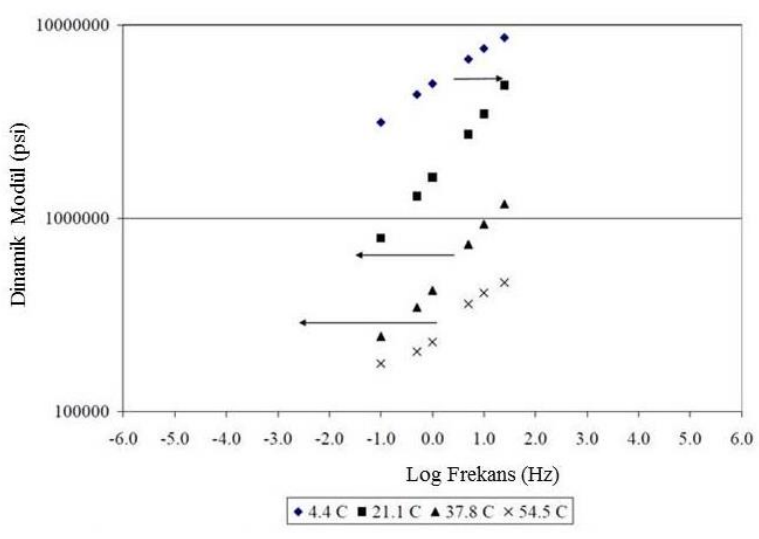

Şekil 3. Test sonuçlarına göre farklı sicaklıklarda dinamik modül frekans eğrileri [12]

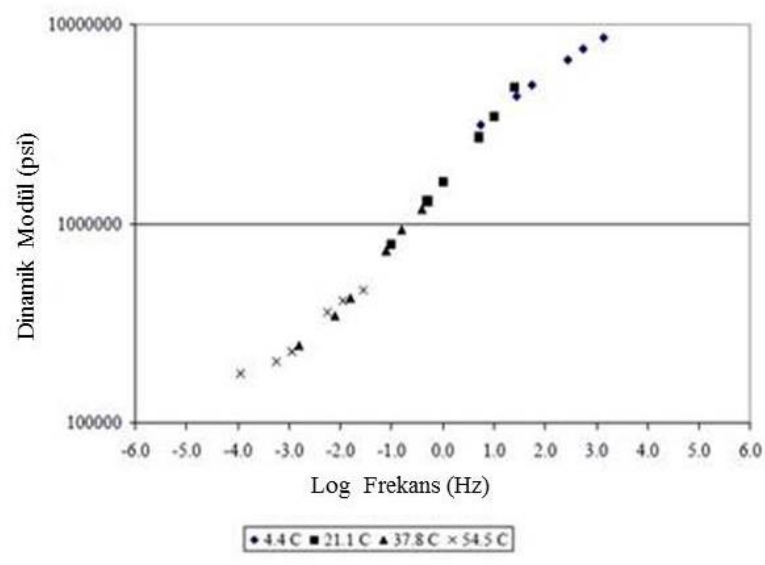

Şekil-4. Test sonuçlarına gore düzeltilmiş dinamik modül ana ĕgrisi [12]

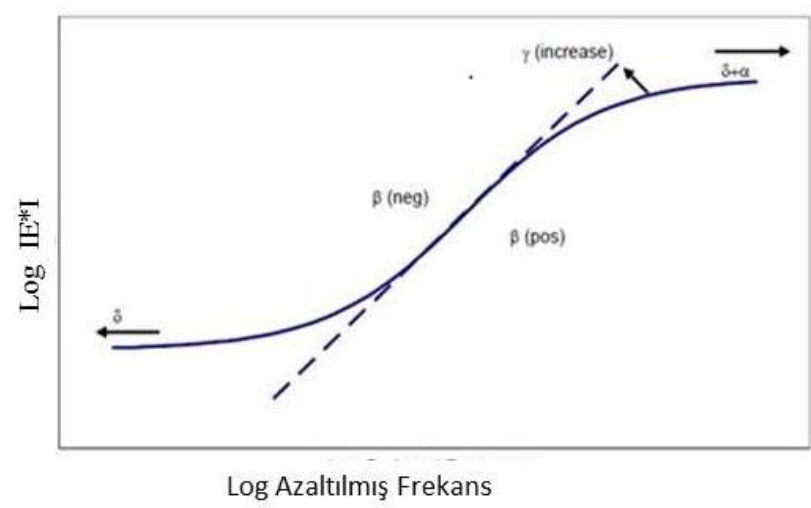

Şekil 5. Sigmodal fonksiyon [13]

$\log \left|E^{*}\right|=\delta+\frac{\alpha}{1+e^{\beta+\gamma \log \left(t_{r}\right)}}$

$\log \left(t_{r}\right)=\log (t)+\log (a(T))$

$\log \left(f_{r}\right)=\log (f)+\log (a(T))$

$\left|\mathrm{E}^{*}\right|$ dinamik modül, $\delta$ minumum modül değeri $\mathrm{t}_{\mathrm{r}}$ referans sıçaklığında azaltılmış yükleme 
süresi,$\delta+\alpha$ maksimum modül değeri $, \beta, \gamma$ sigmodal fonksiyonun şeklini tanımlayan parametreler $\mathrm{a}(\mathrm{T})$ değiştirme faktörü ,t yükleme süresi ,f yükleme frekansı, $f_{r}$ referans sıcaklığında azaltılmış yükleme frekansıdır.

Hiyearşik olarak birinci seviye projeler için dinamik modül, superpave tasarımının bağlayıcı değerleriyle beraber laboratuvar deneylerinden tespit edililmektedir.Dinamik modül deneyleri zamanın yanı sıra ortalama 80.000 \$ ekipman maliyeti gerektirmektedir [14] . İkinci seviye projelerde dinamik modül için deney gerekmezken; bağlayıcılar için geleneksel bitüm deneyleri yapılmaktadır. Üçüncü seviye projeler için ise dinamik modül ve bağlayıcı deneyleri yapılmamakta olup;bağlayıcılar için tasarım rehberinde belirtilen değerler dikkate alınarak, yaşlanmayı da kapsayan zaman sıcaklık ilişkisini gösteren ana eğrileri teşkil edilir [15].

İkinci ve üçüncü seviye projeler için .1954 y1lından itibaren hacimsel hesaplamalara dayanan karışım dizaynlarının (Marshall ,Hvem vb) otuz yıla yakın sürede ölçülen dinamik modül değerlerinin sonuçlarına göre çoğu ABD kaynaklı olan,agrega boyutu ve bağlayıcıların viskozitesiyle ilişkili dinamik modülü tahmin eden modeler geliştirilmiştir.Genellikle Witczak 1999, Witczak 2002 Yeni Witczak 2006 Asfalt Enstitüsü (AI),Hirsch Alkhateeb modelleriyle tahminler yapılmaktadır[16,17]. Geleneksel Witczak 1999, Witczak 2002 modelleri karışım özellikleriyle bereber bağlayıcıların dinamik kesme modülü ve faz acısıyla ilişkilidir.Ülkeler veya bölgeler kendi koşullarına dikkate alarak dinamik modül veri tabanlarıma göre bu modelleri modifiye etmekte veya kendi koşularına uygun tahmin modelleri geliştirmektedir.Idaho,Florida karışımlarının dinamik modüllerinin tahmin modelleri örnek olarak gösterilebilinir.Yerel koşullara ait dinamik modül verilerine uyarlanmış modeller tasarımcıya yerel malzemeleri daha iyi tanıma, farklı tasarım amaçları için uygun maliyetli malzeme seçimi ve bitümlü kaplamaların performansının daha gerçekçi ön görülmesini sağlayacaktır.
Kaplama karışımlarının kalite özelliklerini yansıtan dinamik modülün, tahmininde yaygın olarak kullanılan tahmin modellerinden Witczak1996 (Eşitlik 7),Yeni Witczak 2002 Modeli (Eşitlik 8) eşitlikleri aşagıda gösterilmiştir.

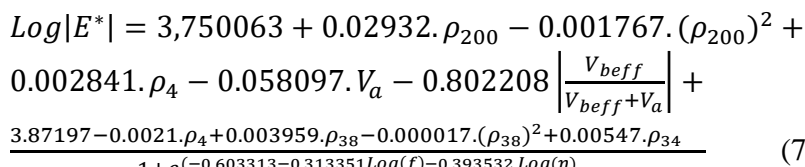

$\log \left|E^{*}\right|=-1.249937+0.029232 . \rho_{200}-$

0.001767. $\left(\rho_{200}\right)^{2}+0.002841 . \rho_{4}-0.058097 . V_{a}-$

$0.802208\left|\frac{V_{\text {beff }}}{V_{\text {beff }}+V_{a}}\right|+$

3.871977-0.0021. $\rho_{4}+0.003959 . \rho_{38}-0.000017 .\left(\rho_{38}\right)^{2}+0.00547 . \rho_{34}$ $1+e^{(-0.603313-0.313551 \log (f)-0.593532 \log (\eta)}$

$\log \log (\eta)=A+V T S \cdot \log \left(T_{R}\right)$

$\log (\eta)=10.5012-2.2601 \log ($ pen $)+$ $0.00389(\log (\text { pen }))^{2}$

$\eta$ bitümün viskozitesi (106 Poise ),f yükleme frekans1, $\mathrm{V}_{\mathrm{a}}$ hava boşluğu $\%, \mathrm{~V}_{\text {beff }}$ hacimsel olarak efektif bitim $\%, \quad, \rho_{4}, \rho_{38,}, \rho_{34}$ No4,3/8",3/4" elekler üzerinde kalan $/ \%$ ), , $\rho_{200} N o 200$ elekten geçen $(\%), \mathrm{T}_{\mathrm{R}}$ sicaklik (Rankine), A regresyon kesmesi,,VTS viskozite sıcaklık duyarlılığının regresyon eğimi, pen bitümün penetrasyondur.

Asfalt betonu karışımlarının rijitlik, esneklik modülü ve ölçülen dinamik modülle tahmin edilen dinamik modül arasında ilişkiyi; agrega gradasyonu, bağlayıcı sınıfi, miktarı, yeni malzeme tipleri, yükleme süresi ve sıcaklık faktörlerine göre degerlendiren bazı çalışmaların sonuçları aşağıda belirtilmiştir.

Kuloğlu,Henkelom-Klomp eşitliklerinde değişen boşluk oranları, bitüm özgül ağırlığı, agrega efektif özgül ağırlığı, agrega ve bitüm yüzdelerine göre karışım rijitlik değerlerini $22019 \mathrm{MPa}$ ile 33042MPa, karışımın plastik rijitliğini ise değișen bitüm viskozitesi ve yükün toplam etkime sürelerine göre $411 \mathrm{MPa}$ ile 2596 MPa aralığında tespit etmştir. [18]

Sayın, Henkelom-Klomp eşitlikleri kullanarak farklı numune sıcaklıklarında bulmuş olduğu 
karışım rijitlikleri bulanık mantık yöntemiyle karşılaştırma çalışmasında -10, 0, 10, 20, 30, $40{ }^{\circ} \mathrm{C}$ numune sicaklıkları için sirasıyla 16008 $\mathrm{MPa}, 10024 \mathrm{MPa}, 5385 \mathrm{MPa} 2262 \mathrm{MPa}, 605$ MPa $51 \mathrm{MPa}$ olarak hesaplamıştır [19].

Özgan, karot numunelerinin 17.30.40.50 ${ }^{\circ} \mathrm{C}$ sicaklıklarda Marshall akma ve stabilite değerlerine göre Nijboer yaklaşımı ile karotların rijitlik modülünü $403 \mathrm{~kg} / \mathrm{cm}^{2}$ (39 $\mathrm{MPa}$ ) ile 192 $\mathrm{kg} / \mathrm{cm}^{2}(19 \mathrm{MPa})$ aralığ 1 da belirlemiştir [20].

Y1lmaz $19 \mathrm{~mm}$ maksimum boyutlu kalker ve kalker + çelik cürufu karışımlı agregalara B160/ 220, B50/70 sinıfi bitümler ve bunların modifiye edilmiş tipleriyle yapılan karışımlara 5,20,35 ${ }^{\circ} \mathrm{C}$ sicaklıklarda uygulanan indirekt çekme rijitlik modülü deneyinde rijitlik modülünü yaklaşı $500 \mathrm{MPa}$ ile $7500 \mathrm{MPa}$ arasında hesaplamıştır[21].

Alataş, maksimum agrega dane boyutu $19 \mathrm{~mm}$ olan kalker ve bazalt agregalı karışımların Marshall numunelerine $20{ }^{\circ} \mathrm{C}$ 'de yaptığı tekrar yüklemeli inderekt çekme deneylerinden bazalt agregalı karışım için $1706 \mathrm{MPa}$ kalker karışım için ise $1353 \mathrm{MPa}$ olarak esneklik modülü sonuçları elde etmiştir [22].

Garcia ve Thompson, dinamik modülün sıcaklıkla ilişkisi çalışmasında,PG64-22, PG 7622,38 sınıfı ve nodifiye edilmiş bitümleri kullanarak;19 mm,12.50 $\mathrm{mm}, 9.50 \quad \mathrm{~mm}$ maksimum boyutlu agrega karışımlarına -10 4 ${ }^{\circ} \mathrm{C} .20{ }^{\circ} \mathrm{C}$ sicaklık ve $25 \mathrm{~Hz}$ ile $0.1 \mathrm{~Hz}$ aralığında yüklemelerden ölçülen dinamik modüller 8.883.851 psi (61.298 Mpa) ile 156120 psi (1077 MPa) aralığındadır. Dinamik modülün tahmininde yaygin olarak kullanılan Hirsch Modeliyle deneyde ölçülen dinamik modüller arasında (Eöl=DF.Et ) düzeltme faktörüün (DF) 0.96 ile 1.43 arasında değiştiği tespit edilmiştir [23].

Thomas, PG64-22, PG76-22 sinıfı bitümlerle maksimuma agrega boyutu $25 \mathrm{~mm}$ ve $9 \mathrm{~mm}$ olan karışımlara laboratuvar ve standart performans deneyleri yapılmiştır. Frekansın artmasıyla dinamik nodülün arttığı, teker izi oturmalarına karşı dinamik modülün yüksek olması gerektiği, ayrıca tahmini edilen dinamik modülle (Witczak ,Hirsch ) ölçülen dinamik modül arasında $\quad \% 10 \quad$ farklilıklar olduğu;.TxDOT (Teksas Taşıma Departmanının)standart performans testlerinde $20 \mathrm{~Hz}, 25 \mathrm{~Hz}$ ile $0.1 \mathrm{~Hz}$ frekans aralığında $5 \mathrm{sn}$ yüklemeli 5 sn yüklemesiz) $0.60 \mathrm{~mm}$ çatlak genişliği esas alınarak yükleme sayılarına göre çatlakların meydana geldiği dinamik modüller belirlenmiştir.[24]

$\mathrm{Yu}$,geri dönüştürülmüş asfalt karışımlı çatı kaplamalarının asfalt karışımlarda kullanılması durumunda ölçülen dinamik modellerin, tahmin edilen dinamik modellerin yaklaşık \%70'i olduğumdan; istatistik değerler $\left(\mathrm{R}^{2}, \mathrm{~S}_{\mathrm{e}} / \mathrm{S}_{\mathrm{y}}\right)$ göz önüne alarak tahmini model eşitliklerini yeniden güncellemiştir [25].

Huanan ,PG64-22,PG64 -28, PG76-28 PG70-28 sınıfı bitümlerle $\% 20$ oranında geri kazanılmış asfalt kaplamaların kullanıldığ 1 maksimum dane boyutu $19 \mathrm{~mm}$ ve ortalama bitüm yüzdesi \% 5.40 olan karışımlara $0.1 \mathrm{~Hz} 130{ }^{\circ} \mathrm{F}$ 'da yapılan dinamik modülü deneylerinde PG 76-28 sınıfı bitümün diğer bitümlere göre belirgin bir şekilde dinamik modülü yükselttiği, $1 \mathrm{~Hz}, 140$ ${ }^{\circ} \mathrm{F}$ 'da bitüm sınıflarının dinamik modülü çok fazla etkilemediğini tespit etmistir.Bitüm ve boşluk yüzdesinin artışıyla dinamik modülün azaldığg1, agrega gradasyonunun dinamik modül üzerinde etkisi olduğu; ayrıca kompozit malzemeler için Hirsch modelinin daha uygun olacağını belirtmiştir[,26].

Hyun, Jong, Lee ,modifiye bitümlü kaplamların geleneksel kaplamalara göre dinamik modülünün daha yüksek ve performansının daha iyi olduğunu laboratuvar ve saha testleriyle tespit etmistir [,27].

Güngör ve Sağlik, TÜBİTAK projesinde B 50/70 bitümle aşınma (kireçtaş1) ,taş mastik aşınma (kireçtaşı) , aşınma (bazalt), binder (kireçtaş1) ve bitümlü temel (kireçtaşı) karışımların esneklik modülü sırayla $5245 \mathrm{MPa}$, $4338 \mathrm{MPa}, 4487 \mathrm{MPa} 4306 \mathrm{MPa}$ modifiye bitümlü kireç taşı ve bazalt agregalı aşınma karışımları için sırasıyla $5970 \mathrm{MPa}, 4767$ $\mathrm{MPa}$, bazalt agregalı modifiyeli ve modifiyesiz taş mastik karışımlar için ise sırasıyla 4313 $\mathrm{MPa}, 3906 \mathrm{MPa}$ olarak tespit edilmiş olup; Witzack formülüne benzer $4 \mathrm{~Hz}^{\prime} \mathrm{de}$ dinamik 
rijitlik modülün tahmininde kullanılabilecek eşitlik geliştirmiştir[28].

Srempihar,elyaf katkılı ve katkısız karışımların $40{ }^{\circ} \mathrm{F}$ ile $100 \quad$ oF sicakliklarda esneklik modüllerini karşılaştırmış,elyaf katkı1ı karışımların $100{ }^{\circ} \mathrm{F}$ katkısıza göre esneklik modülünü 2 kat arttığı aynı sıcaklıkta $5 \mathrm{~Hz}$ frekans yüklemede esneklik modülü ile dinamik modülünün eşdeğer olduğunu belirleten araştırmalara benzer sonuçları elyaflı katkılı karışımlar içinde elde etmiştir. [29].

Esfandiarpour ve Shalaby, $\% 10$ ile $\% 50$ arasında değişen oranlarda geri kazanılmış asfalt kaplama karışımlarının kullanıldığ karışımların dinamik modülünün tahminini, amprik ve analitik kaplama tasarımına göre değerlendirilme çalışmasında,seviye iki için yüksek sıcaklık ve düşük sıcaklıklarda tahmin edilen dinamik modülün ölçülenin yarısı, seviye üç için ise yüksek sicaklıklarda ortalama $\% 50$ düşük sıcaklıklarda ise $\% 150$ oranında fazla tespit edilmiş olup ;ölçülenle tahmin edilen dinamik modüller arasında istatistiksel kriterler için korelasyon çalışmaları yapmıştır [30].

MJeong,değişik yüzdelerde geri kazanılmış asfalt kaplama karışımlarınn kullanıldığ modifiye edilmiş karışımların beş sıcaklık ve ,altı yükleme frekansında ölçülen dinamik modülleri, Witczak 1999 ve 2006 modelleri ile tahmin edilenlerle karşılaştırma çalışmasında 1999 modelinden istatistiksel olarak daha iyi sonuçlar elde edilmiştir [31].

\section{Metodoloji}

Çalışmada bazalt taş ocağından üretilen $\begin{array}{llll}\text { agregalara Karayolları } & 18 \quad \text { Bölge }\end{array}$ Laboratuvarında yapılan bitümlü temel, binder, aşınma Marshall dizaynlarındanından yararlanılarak $(25,10,5,1,0.5,0,1,0.05,0.025) \mathrm{Hz}$ frekans ve $(-10,0,4.4,21,1,37.8,54.4)^{\circ} \mathrm{C}$ sıcaklıklarda Witczak 2002 (Eşitlik 7) modeliyle dinamik rijitlik modülleri hesaplanmış;.21.1 ${ }^{\circ} \mathrm{C}$ referans sicaklığında kaplama karışımlarının Excel'de dinamik rijitlik modülü ana eğrisi,(master curve) cizilmiştir.Tabakalar için yapılan Marshall dizaynlnda değişen bitüm yüzdelerine gore

tahmini dinamik rijitlik modülü hesaplanarak;Marshall dizaynından elde edilen ,boşluk, asfaltla dolu boşluk, stabilite,akma ,agregalar arası boşluk ve hacimsel özgül ağırlıkla ilişkisi araştırılmıştır.

\section{Deneysel - Teorik Çalışma}

Bazalt taş ocağından konkasörde üretilen 11/2"3/4", 1"-3/4", 3/4"-1/2",1/2"-No4,ve No4-alt1 agrega gruplarından bitümlü temel, binder, aşınma tabakaları için elde edilen karışım gradasyonlarında (Tablo-1) B 70/100 sinifi bitüm kullanılarak farklı bitüm yüzdelerinim her birinde üç adet numune hazırlanarak bu tabakalara ait yapılan Marshall dizaynından elde edilen sonuçlar Tablo 2'de gösterilmiştir.

Tablo 1. Bitümlü temel, binder, aşınma tabakalarının agrega karışım gradasyonları

\begin{tabular}{|c|c|c|c|c|c|c|}
\hline \multirow[b]{2}{*}{$\begin{array}{l}\text { Elek } \\
\text { Açık. } \\
\text { (inch) }\end{array}$} & \multicolumn{2}{|c|}{ Bitümlü Temel } & \multicolumn{2}{|c|}{ Binder } & \multicolumn{2}{|c|}{ Aşınma } \\
\hline & $\begin{array}{l}\text { Dizayn } \\
\text { Grad } \\
.(\%)\end{array}$ & $\begin{array}{l}\text { Şart. } \\
\text { Grad } \\
(\%) .\end{array}$ & $\begin{array}{l}\text { Dizayn } \\
\text { Grad } \\
.(\%)\end{array}$ & $\begin{array}{l}\text { Şart. } \\
\text { Grad } \\
(\%)\end{array}$ & $\begin{array}{l}\text { Dizayn } \\
\text { Grad } \\
.(\%)\end{array}$ & $\begin{array}{l}\text { Şart. } \\
\text { Grad } \\
(\%) .\end{array}$ \\
\hline $11 / 2 "$ & 100 & 100 & 100 & 100 & 100 & 100 \\
\hline $1 "$ & 88,29 & $72-100$ & 100 & 100 & 100 & 100 \\
\hline 3/4" & 76,49 & $60-90$ & 90,54 & $100-80$ & 100 & 100 \\
\hline $1 / 2^{\prime \prime}$ & 62,44 & $50-78$ & 71,29 & $58-80$ & 91,048 & $80-100$ \\
\hline $3 / 8 "$ & 55,89 & $43-70$ & 62,2 & $48-70$ & 80,456 & $72-90$ \\
\hline No.4 & 40,51 & $30-55$ & 43,01 & $30-52$ & 46,344 & $42--52$ \\
\hline No.10 & 25,15 & $18-42$ & 26,78 & $20-40$ & 28,512 & $25--35$ \\
\hline No.40 & 10,68 & $6--21$ & 11,91 & $8--22$ & 12,936 & $10--20$ \\
\hline No. 80 & 6,57 & $2--13$ & 7,26 & $5--14$ & 8,096 & 7--14 \\
\hline No.200 & 3,66 & $0-7$ & 4,14 & $2--7$ & 4,84 & $3--8$ \\
\hline
\end{tabular}

Tablo 2.a Bitümlü temel tabakası Marshall deney sonuçları

\begin{tabular}{|c|c|c|c|c|c|c|c|c|}
\hline Grup No & $\begin{array}{c}\text { Bitüm } \\
\text { Wa } \\
(\%)\end{array}$ & $\begin{array}{c}\text { Hacim } \\
\text { Özg.Ağrrl } \\
\text { Dp }\end{array}$ & $\begin{array}{c}\text { Maks.Teo. } \\
\text { Özgül Ağ. } \\
\text { Dt }\end{array}$ & $\begin{array}{c}\text { Boşluk } \\
\text { Vh } \\
(\%)\end{array}$ & $\begin{array}{c}\text { V.M.A } \\
(\%)\end{array}$ & $\begin{array}{c}\text { Asf.Dol } \\
\text { Boş. } \\
(\%)\end{array}$ & $\begin{array}{c}\text { Akma } \\
(\mathrm{mm})\end{array}$ & $\begin{array}{c}\text { Düzeltm } \\
\text { Stabilite } \\
(\mathrm{kg})\end{array}$ \\
\hline 1 & 3 & 2,179 & 2,43 & 10,376 & 15,2 & 31,72 & 2,99 & 865,64 \\
2 & 3,5 & 2,204 & 2,42 & 8,751 & 14,64 & 40,22 & 2,74 & 944,42 \\
3 & 4 & 2,231 & 2,4 & 7,037 & 14,01 & 49,77 & 2,84 & 1058,78 \\
4 & 4,5 & 2,248 & 2,38 & 5,716 & 13,75 & 58,45 & 2,48 & 1133,65 \\
5 & 5 & 2,255 & 2,37 & 4,85 & 13,92 & 65,15 & 2,6 & 1183,53 \\
6 & 5,5 & 2,25 & 2,36 & 4,473 & 14,51 & 69,18 & 2,64 & 1104,2 \\
7 & 6 & 2,246 & 2,34 & 4,076 & 15,08 & 72,97 & 2,73 & 1071,34 \\
Dizayn & 5,04 & 2,256 & 2,368663 & 4,756 & 13,9084 & 65,80197 & 2,66 & 1150 \\
Şartname & $3,5-6,5$ & -- & -- & $4--6$ & $13-15$ & $60-75$ & $2--4$ & Min 750 \\
\hline
\end{tabular}


Tablo 2.b. Binder tabakası Marshall deney sonuçları

\begin{tabular}{|c|c|c|c|c|c|c|c|c|}
\hline Grup No & $\begin{array}{c}\text { Bitüm } \\
\text { Wa } \\
(\%)\end{array}$ & $\begin{array}{c}\text { Hacim } \\
\text { Özg.Ağrl } \\
\text { Dp }\end{array}$ & $\begin{array}{c}\text { Maks. Teo. } \\
\text { Özgül Ağ. } \\
\text { Dt }\end{array}$ & $\begin{array}{c}\text { Boşluk } \\
\text { Vh } \\
(\%)\end{array}$ & $\begin{array}{c}\text { V.M.A } \\
(\%)\end{array}$ & $\begin{array}{c}\text { Asf.Dol } \\
\text { Boș. } \\
(\%)\end{array}$ & $\begin{array}{c}\text { Akma } \\
(\mathrm{mm})\end{array}$ & $\begin{array}{c}\text { Düzeltm } \\
\text { Stabilite } \\
(\mathrm{kg})\end{array}$ \\
\hline 1 & 3 & 2,179 & 2,43 & 10,376 & 15,2 & 31,72 & 2,99 & 865,64 \\
2 & 3,5 & 2,204 & 2,42 & 8,751 & 14,64 & 40,22 & 2,74 & 944,42 \\
3 & 4 & 2,231 & 2,4 & 7,037 & 14,01 & 49,77 & 2,84 & 1058,78 \\
4 & 4,5 & 2,248 & 2,38 & 5,716 & 13,75 & 58,45 & 2,48 & 1133,65 \\
5 & 5 & 2,255 & 2,37 & 4,85 & 13,92 & 65,15 & 2,6 & 1183,53 \\
6 & 5,5 & 2,25 & 2,36 & 4,473 & 14,51 & 69,18 & 2,64 & 1104,2 \\
7 & 6 & 2,246 & 2,34 & 4,076 & 15,08 & 72,97 & 2,73 & 1071,34 \\
Dizayn & 5,04 & 2,256 & 2,368663 & 4,756 & 13,9084 & 65,80197 & 2,66 & 1150 \\
Sartname & $3,5-6,5$ & -- & -- & $4--6$ & $13-15$ & $60-75$ & $2--4$ & Min 750 \\
\hline
\end{tabular}

Tablo 2.c. Aşınma tabakası Marshall deney

$$
\text { sonuçları }
$$

\begin{tabular}{|c|c|c|c|c|c|c|c|c|}
\hline Grup No & $\begin{array}{c}\text { Bitüm } \\
\text { Wa } \\
(\%)\end{array}$ & $\begin{array}{c}\text { Hacim } \\
\text { Özg.Ağrl } \\
\text { Dp }\end{array}$ & $\begin{array}{c}\text { Maks.Teo. } \\
\text { Özgül Ağ. } \\
\text { Dt }\end{array}$ & $\begin{array}{c}\text { Boşluk } \\
\text { Vh } \\
(\%)\end{array}$ & $\begin{array}{c}\text { V.M.A } \\
(\%)\end{array}$ & $\begin{array}{c}\text { Asf.Dol } \\
\text { Boş.V } \\
(\%)\end{array}$ & $\begin{array}{c}\text { Akma } \\
(\mathrm{mm})\end{array}$ & $\begin{array}{c}\text { Düzeltm } \\
\text { Stabilite } \\
(\mathrm{kg})\end{array}$ \\
\hline 1 & 3,5 & 2,152 & 2,41 & 10,79 & 16,53 & 34,7 & 2,41 & 950,47 \\
2 & 4 & 2,175 & 2,4 & 9,25 & 16,05 & 42,3 & 2,45 & 1065,78 \\
3 & 4,5 & 2,194 & 2,38 & 7,872 & 15,71 & 49,9 & 2,65 & 1092,2 \\
4 & 5 & 2,23 & 2,37 & 5,801 & 14,76 & 60,71 & 2,95 & 1111,08 \\
5 & 5,5 & 2,249 & 2,35 & 4,416 & 14,45 & 69,43 & 2,99 & 1164,93 \\
6 & 6 & 2,244 & 2,34 & 4,019 & 15,01 & 73,23 & 3,11 & 1153,92 \\
7 & 6,5 & 2,238 & 2,32 & 3,73 & 15,66 & 76,18 & 2,81 & 1153,92 \\
Dizayn & 5,54 & 2,246 & 2,351417 & 4,483 & 14,58175 & 69,25524 & 2,84 & 1151 \\
Şartname & $4--7$ & -- & -- & $3--5$ & $14-16$ & $60-75$ & $2--4$ & Min 900 \\
\hline
\end{tabular}

Tabakaların Marshall deneyinde belirtilen farklı bitüm yüzdeleriW $W_{a}$ ) için agregaların bitüm absobsiyonu ( $\left.\mathrm{P}_{\mathrm{abs}}\right)$,karışımın efektif bitümü ( $\left.P_{\text {Efbit }}\right)$,bitüm özgül ağırlığı $\left(\mathrm{G}_{\text {bit }}\right)$ ve biriketlerin hacimsel özgül ağırlığıyla $\left(D_{p}\right)$ ilişkili olan efektif bitüm yüzdeleri ( $\mathrm{V}_{\text {efbit}}$ ) hacimsel olarak hesaplanarak Tablo 3' de gösterilmiştir.

Tablo 3.a. Bitümlü temel karışımlarının efektif bitüm yüzdeleri

\begin{tabular}{|cccccc|}
\hline $\mathrm{W}_{\mathrm{a}}(\%)$ & $\mathrm{P}_{\mathrm{abs}}(\%)$ & $\mathrm{P}_{\text {efbit }}(\%)$ & $\mathrm{D}_{\mathrm{p}}$ & $\mathrm{G}_{\mathrm{bit}}$ & $\mathrm{V}_{\text {effbit }}(\%)$ \\
\hline 2,5 & 0,73 & 1,77 & 2,188 & 1,028 & 3,702 \\
3 & 0,73 & 2,27 & 2,201 & 1,028 & 4,752 \\
3,5 & 0,73 & 2,77 & 2,225 & 1,028 & 5,833 \\
4 & 0,73 & 3,27 & 2,259 & 1,028 & 6,958 \\
4,5 & 0,73 & 3,77 & 2,25 & 1,028 & 7,952 \\
5 & 0,73 & 4,27 & 2,248 & 1,028 & 8,954 \\
5,5 & 0,73 & 4,77 & 2,241 & 1,028 & 9,927 \\
Dzy 4,65 & 0,73 & 3,92 & 2,257 & 1,028 & 8,282 \\
\hline
\end{tabular}

Tablo 3.b. Binder karışımlarının efektif bitüm yüzdeleri

\begin{tabular}{|cccccc|}
\hline $\mathrm{W}_{\mathrm{a}}(\%)$ & $\mathrm{P}_{\mathrm{abs}}(\%)$ & $\mathrm{P}_{\text {efbit }}(\%)$ & $\mathrm{D}_{\mathrm{p}}$ & $\mathrm{G}_{\mathrm{bit}}$ & $\mathrm{V}_{\text {effbit }}(\%)$ \\
\hline 3 & 0,66 & 2,34 & 2,179 & 1,028 & 4,847 \\
3,5 & 0,66 & 2,84 & 2,204 & 1,028 & 5,921 \\
4 & 0,66 & 3,34 & 2,231 & 1,028 & 7,014 \\
4,5 & 0,66 & 3,84 & 2,248 & 1,028 & 8,088 \\
5 & 0,66 & 4,34 & 2,255 & 1,028 & 9,124 \\
5,5 & 0,66 & 4,84 & 2,25 & 1,028 & 10,104 \\
6 & 0,66 & 5,34 & 2,246 & 1,028 & 11,074 \\
Dzy 5,04 & 0,66 & 4,38 & 2,256 & 1,028 & 9,209 \\
\hline
\end{tabular}

Tablo 3.c. Aşınma karışımlarının efektif bitüm yüzdeleri

\begin{tabular}{|cccccc|}
\hline $\mathrm{W}_{\mathrm{a}}(\%)$ & $\mathrm{P}_{\mathrm{abs}}(\%)$ & $\mathrm{P}_{\text {efbit }}(\%)$ & $\mathrm{D}_{\mathrm{p}}$ & $\mathrm{G}_{\text {bit }}$ & $\mathrm{V}_{\text {effbit }}(\%)$ \\
\hline 3,5 & 0,66 & 2,84 & 2,152 & 1,028 & 5,781 \\
4 & 0,66 & 3,34 & 2,175 & 1,028 & 6,838 \\
4,5 & 0,66 & 3,84 & 2,194 & 1,028 & 7,894 \\
5 & 0,66 & 4,34 & 2,23 & 1,028 & 9,022 \\
5,5 & 0,66 & 4,84 & 2,249 & 1,028 & 10,098 \\
6 & 0,66 & 5,34 & 2,244 & 1,028 & 11,067 \\
6,5 & 0,66 & 5,84 & 2,238 & 1,028 & 12,011 \\
Dzy 5,54 & 0,66 & 4,88 & 2,246 & 1,028 & 10,166 \\
\hline
\end{tabular}

Karışımlarda kullanılan B70/100 sınıfı bitümün performans siniflandirılması PG 64-28 kabul edilerek bu performansa ait $A$ ve VTS parametreleri sirasiyla $10.312,-3.440$ alınarak farklı sıcaklıklarda Eşitlik 9'a göre bitüm viskozitesi hesaplanmıştır (Tablo-4).

Tablo 4. Bitüm viskozite değerleri

\begin{tabular}{|cc|}
\hline $\mathrm{T}\left({ }^{\circ} \mathrm{C}\right)$ & $\mathrm{n}\left(\right.$ Poise $\left.10^{6}\right)$ \\
\hline-10 & 68238,23 \\
0 & 1943,84 \\
4,4 & 484,01 \\
21,1 & 5,48688 \\
37,8 & 0,16897 \\
54,4 & 0,01106 \\
\hline
\end{tabular}

Karışımların farklı frekans $(25,10,5,1,0.5,0,1,0.05,0.025) . H z . v e \quad(-10,0,4$ $4,21 \quad 1,37 \quad 8,54 \quad 4 \quad)^{\circ} \mathrm{C}$ sicakliklarda dinamik rijitlik modülü Eşitlik 7'ye göre hesaplanarak Tablo 5' te gösterilmiştir .Bu değerlere göre aynı sıcaklıkta frekans azaldıkça ve aynı frekansta sıcaklık yükseldikçe dinamik rijitlik modülün azaldığı; ayrıca maksimum dane boyutuna göre $19.10 \mathrm{~mm}$ elek üzerinde kalan malzeme miktarı artıkça dinamik rijitlik modülünün artığı bu nedenle bitümlü temelin bitümlü tabakalar arasında en yüksek dinamik rijitlik modülüne sahip olduğu tespit edilmiştir

Tablo 5.a. Aşınma karışımlarının farklı frekans ve sicaklıklara göre hesaplanan dinamik rijitlik modülü

\begin{tabular}{|c|cccccc|}
\hline \multirow{2}{*}{$\mathrm{f}(\mathrm{Hz})$} & \multicolumn{6}{|c|}{ Sicaklik $^{\mathrm{O}} \mathrm{C}$} \\
\cline { 2 - 7 } & -10 & 0 & 4,4 & 21,11 & 37,8 & 54,4 \\
\cline { 2 - 7 } & & \multicolumn{6}{|c|}{$\mathrm{E}(\mathrm{psi})$} \\
\hline 25 & 3301590 & 2357617 & 1957726 & 814234 & 295910 & 113182 \\
10 & 3123971 & 2148000 & 1749624 & 674523 & 231433 & 86242 \\
5 & 2983238 & 1988996 & 1595275 & 579922 & 190974 & 70088 \\
1 & 2638381 & 1625420 & 1254355 & 396999 & 120218 & 43282 \\
0,5 & 2483712 & 1474193 & 1117767 & 333368 & 97969 & 35240 \\
0,1 & 2116714 & 1144117 & 831221 & 217006 & 60543 & 22107 \\
\hline
\end{tabular}


Tablo 5.b. Binder karışımlarının farklı frekans ve sicaklıklara göre hesaplanan dinamik rijitlik modülü

\begin{tabular}{|c|cccccc|}
\hline \multirow{3}{*}{$\mathrm{f}(\mathrm{Hz})$} & \multicolumn{6}{|c|}{ Sicakl1k $^{\circ} \mathrm{C}$} \\
\cline { 2 - 7 } & -10 & 0 & 4,4 & 21,11 & 37,8 & 54,4 \\
\cline { 2 - 7 } & \multicolumn{6}{|c|}{$\mathrm{E}(\mathrm{psi})$} \\
\hline 25 & 4038254 & 2858505 & 2362204 & 960291 & 339920 & 126805 \\
10 & 3815511 & 2598052 & 2104944 & 791631 & 264159 & 95941 \\
5 & 3639257 & 2400925 & 1914644 & 677936 & 216892 & 77551 \\
1 & 3208296 & 1951774 & 1496085 & 459544 & 134899 & 47294 \\
0,5 & 3015474 & 1765692 & 1329181 & 384139 & 109350 & 38301 \\
0,1 & 2559234 & 1361341 & 980851 & 247277 & 66735 & 23738 \\
0,05 & 2362292 & 1202196 & 849568 & 202688 & 53925 & 19451 \\
0,025 & 2167193 & 1053581 & 730195 & 165390 & 43621 & 16021 \\
\hline
\end{tabular}

Tablo.5.c Bitümlü temel karışımlarının farklı frekans ve sicaklıklara göre hesaplanan dinamik rijitlik modülü

\begin{tabular}{|c|cccccc|}
\hline \multirow{2}{*}{$\mathrm{f}(\mathrm{Hz})$} & \multicolumn{6}{|c|}{ Sicakl1k ${ }^{\mathrm{O}} \mathrm{C}$} \\
\cline { 2 - 7 } & -10 & 0 & 4,4 & 21,11 & 37,8 & 54,4 \\
\cline { 2 - 7 } & \multicolumn{6}{|c|}{$\mathrm{E}(\mathrm{psi})$} \\
\hline 25 & 4919053 & 3455300 & 2843283 & 1132926 & 391862 & 143008 \\
10 & 4641859 & 3133797 & 2527135 & 929938 & 302819 & 107530 \\
5 & 4422773 & 2890937 & 2293820 & 793635 & 247546 & 86507 \\
1 & 3888100 & 2339304 & 1782553 & 533334 & 152345 & 52179 \\
0,5 & 3649382 & 2111559 & 1579525 & 444045 & 122916 & 42058 \\
0,1 & 3085940 & 1618603 & 1157728 & 283050 & 74194 & 25791 \\
0,05 & 2843391 & 1425432 & 999568 & 230985 & 59668 & 21039 \\
0,025 & 2603558 & 1245556 & 856226 & 187628 & 48040 & 17254 \\
\hline
\end{tabular}

Belirtilen sicaklık ve frekansta hesaplanan aşınma tabakasına ait dinamik rijitlik modülünün değişimi (Şekil 6) $21.1{ }^{\circ} \mathrm{C}$ referans sıcaklığına göre düzeltilmiş frekanslarla (Tablo-6 ) çizilen dinamik riittlik modükü ana eğri Şekil 7`de gösterilmiştir. Bitümlü temel, binder tabakaları içinde aynı hesaplamalar yapılarak dinamik riiitlik modülü ana eğrileri çizilmiştir(Şekil 8).

Tablo 6. Referans sicaklığında $\left(2111{ }^{\circ} \mathrm{C}\right)$ düzeltilmiş frekanslar

\begin{tabular}{|cccccc|}
\hline \multicolumn{7}{c|}{ S1caklık ${ }^{\circ} \mathrm{C}$} \\
\hline-10 & 0 & 4,4 & 21,1 & 37,8 & 54,4 \\
\hline \multicolumn{7}{c|}{ Düzeltilmiş Frekans $\log \left(\mathrm{f}_{\mathrm{r}}\right)$} \\
\hline 6,540403 & 4,599605 & 3,841299 & 1,39794 & $-0,5$ & $-1,98737$ \\
6,142463 & 4,201665 & 3,443359 & 1 & $-0,898$ & $-2,38531$ \\
5,841433 & 3,900635 & 3,142329 & 0,69897 & $-1,199$ & $-2,68634$ \\
5,142463 & 3,201665 & 2,443359 & 0 & $-1,898$ & $-3,38531$ \\
4,841433 & 2,900635 & 2,142329 & $-0,30103$ & $-2,199$ & $-3,68634$ \\
4,142463 & 2,201665 & 1,443359 & -1 & $-2,898$ & $-4,38531$ \\
3,841433 & 1,900635 & 1,142329 & $-1,30103$ & $-3,199$ & $-4,68634$ \\
3,540403 & 1,599605 & 0,841299 & $-1,60206$ & $-3,5$ & $-4,98737$ \\
\hline \multicolumn{7}{c}{} \\
\hline
\end{tabular}



Şekil 6. Farklı sıcaklıklarda aşınma karışımının frekanslara göre dinamik modülü

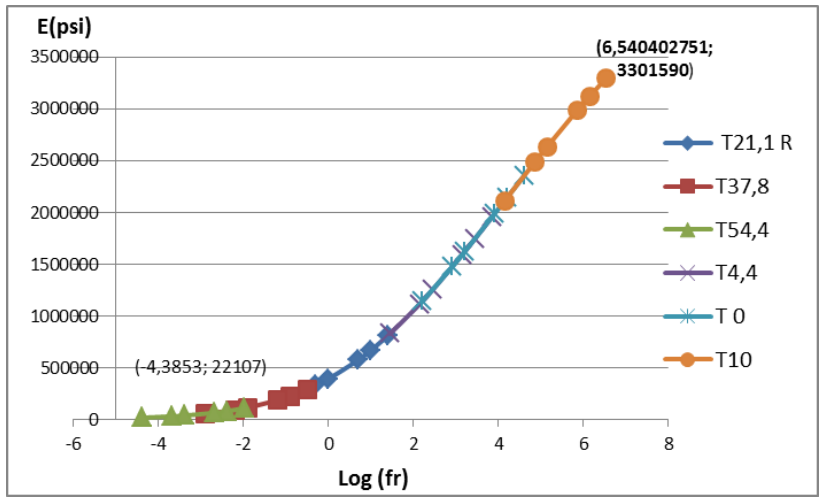

Şekil 7. Referans sıcaklığndai $\left(21,1^{\circ} \mathrm{C}\right)$ aşınma tabakasının dinamik rijitlik modülü ana ĕgrisi

Tabakaların referans sıcaklığına göre çizilen dinamik rijitlik modülü ana eğrilerinden görüleceği (Şekil-8) üzere $1 \mathrm{~Hz}$ 'e kadar dinamik modülleri birbirine yakın olmasına karşın düşük sıcaklıklarda $1 \mathrm{~Hz}$ 'dan büyük frekanslarda tabakaların dinamik modülleri arasında fark atmakta olup; tasarımciların analitik hesaplamalarda bu durumu göz önüne alması ekonomiklik ve yoğum trafigin olduğu kaplamaların performansı acısından önem arz etmektedir

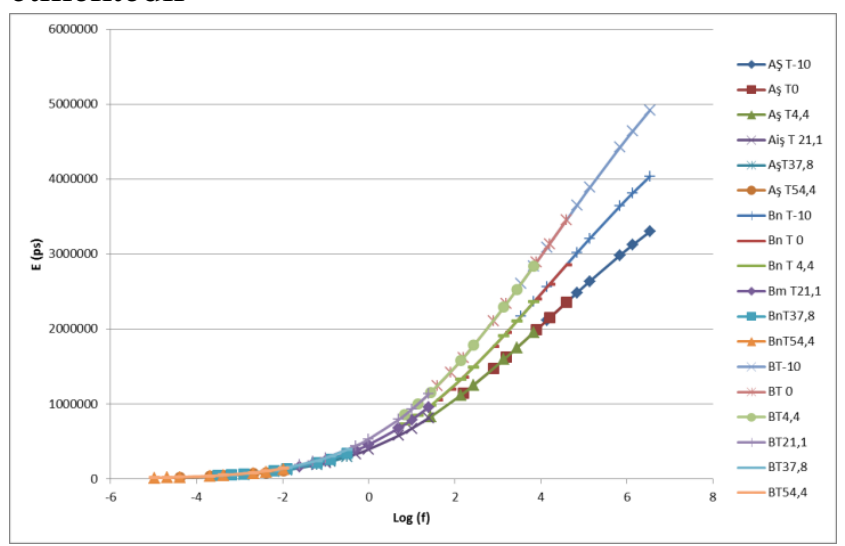

Şekil 8. Referans sicaklı̆̆ndaı $\left(21,1^{\circ} \mathrm{C}\right)$ aşınma binder, bitümlü temel tabakalarının dinamik rijitlik modülü ana eğrileri 
Ülkemizde tabakaların karışım dizaynında yaygın olarak kullanılan Marshall dizaynından elde edilen bitüm yüzdelerine $\left(\mathrm{W}_{\mathrm{a}}\right)$ göre pratik özgül ağırlık $\left(D_{p}\right)$, boşluk $\left(V_{h}\right)$, agregalar arası boşluk (VMA), bitümle dolu boşluk ( $\left.\mathrm{V}_{\mathrm{f}}\right)$, akma ve stabiliteyle tabakaların rijitlik modülü arasında ilişkinin araştırılmasının deney zamanı ,maliyetleri ve tasarımciya analitik hesaplamalarda öngürüde bulunması açısından önemli olduğu düşünülmektedir Tabaka karışımlarınının dizaynında kullanılan bitüm yüzdelerine göre $21,1^{\circ} \mathrm{C}$ referans sicaklığında ve $25 \mathrm{~Hz}$ frekansta $(0,04$ sn yükleme süresi) hesaplanan dinamik rijitlik modüllerle (Tablo 7) aynı bitüm yüzdesine ait Marshall dizayn sonuçları grafik olarak Şekil -9 'da gösterilmiştir. Tabakaların dinamik modülünün Marshall briketi parametreleriyle ilişkisi incelendiğinde; Marshall biriketlerinin $\mathrm{D}_{\mathrm{p}}, \mathrm{V}_{\mathrm{f}}, \mathrm{W}_{\mathrm{a}}$ ve stabilite değerlerinin artışıyla dinamik rijitlik modülü artarak maksimum noktaya ulaştıktan sonra tekrar düştüğü, $\mathrm{V}_{\mathrm{h}}$ ve $\mathrm{VMA}$ değerleri azaldıkça dinamik modülün arttığı, $V_{h}$ belli bir naktada dinamik modülü maksimum yaptıktan sonra boşluğun artmasıyla dinamik modülünde azaldığı tespit edilmiştir.Aşınma karışımlarında optimum bitüm yüzdesinde maksimum dinamik rijitlik modülü elde ederken diger karışımlarda optimum bitümde maksimum dinamik modül elde edilmemiştir.

Tablo 7. Bitüm yüzdesine göre tabakaların dinamik modülü

\begin{tabular}{|cc|cc|cc|}
\hline \multicolumn{2}{|c|}{ Biitümlü Temel } & \multicolumn{2}{c|}{ Binder } & \multicolumn{2}{c|}{ Aşınma } \\
\hline $\mathrm{W}_{\mathrm{a}}$ & $\mathrm{E}(\mathrm{psi})$ & $\mathrm{W}_{\mathrm{a}}$ & $\mathrm{E}(\mathrm{psi})$ & $\mathrm{W}_{\mathrm{a}}$ & $\mathrm{E}(\mathrm{psi})$ \\
\hline 2,50 & 1072405,87 & 3,00 & 850268,44 & 3,50 & 662395,96 \\
3,00 & 1082487,30 & 3,50 & 902898,06 & 4,00 & 707087,63 \\
3,50 & 1126418,55 & 4,00 & 951728,85 & 4,50 & 739358,58 \\
4,00 & 1183213,77 & 4,50 & 967586,26 & 5,00 & 799036,88 \\
4,50 & 1127162,91 & 5,00 & 959926,73 & 5,50 & 818742,88 \\
5,00 & 1096751,07 & 5,50 & 937301,54 & 6,00 & 805088,81 \\
5,50 & 1067039,54 & 6,00 & 921746,32 & 6,50 & 792536,86 \\
Dzy 4,65 & 1132925,83 & Dzy 5,04 & 960451,67 & Dzy 5,54 & 814234,26 \\
\hline
\end{tabular}

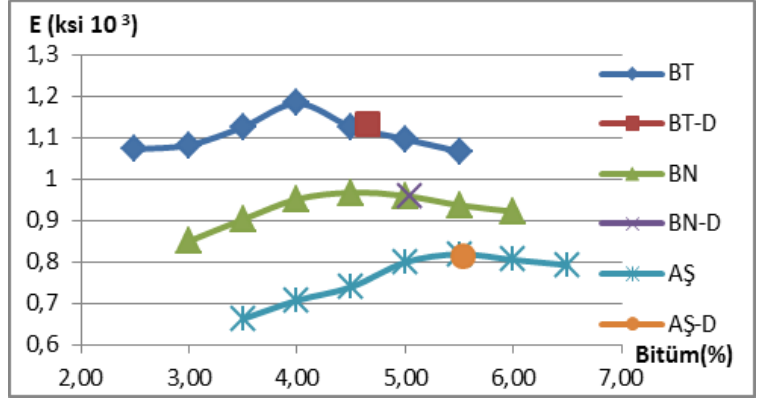

a) Dinamik Modül $-W_{a}$

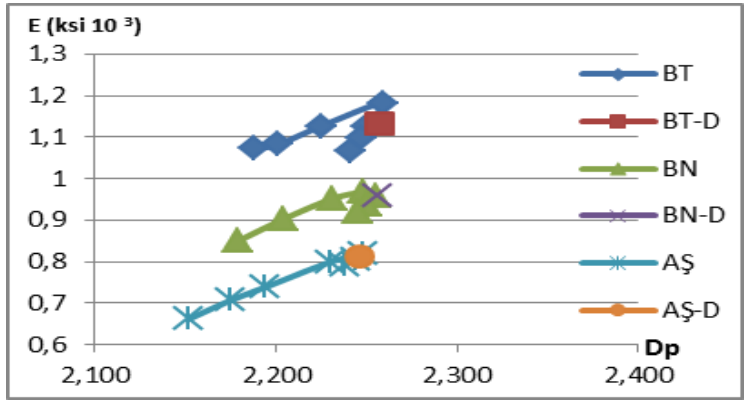

b) Dinamik Modül $-D_{p}$

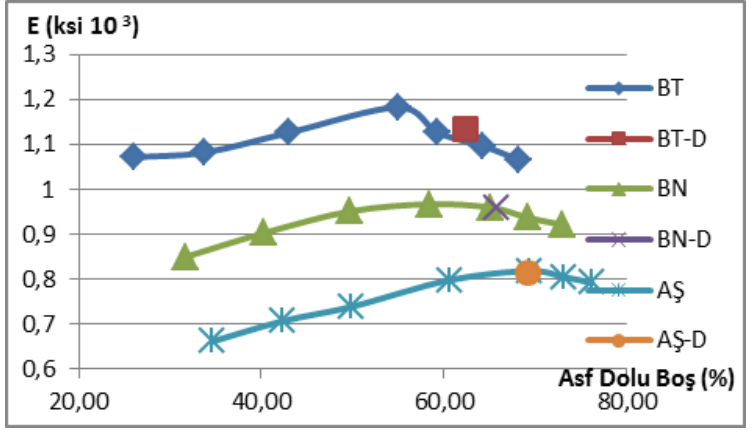

c) Dinamik Modül $-V_{f}$

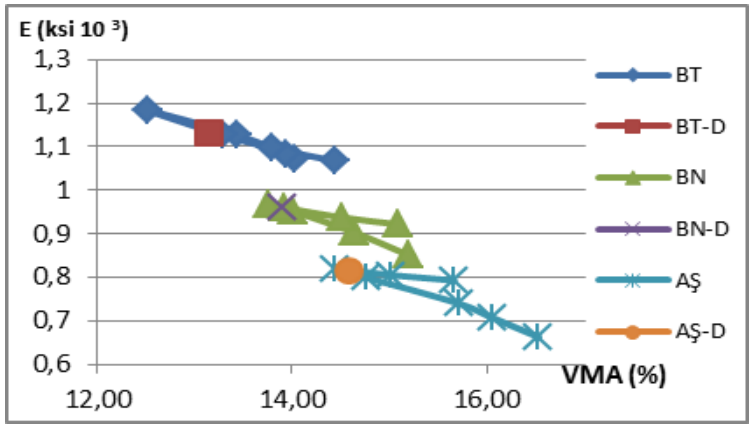

d) Dinamik Modül-VMA 


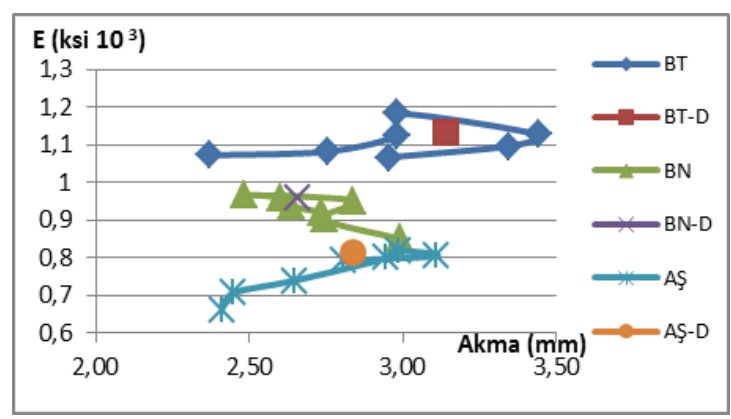

e) Dinamik Modül-Akma

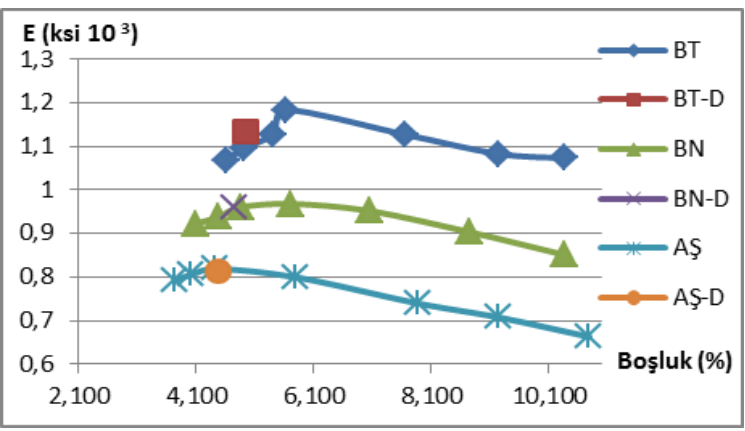

f) Dinamik Modül -Vh

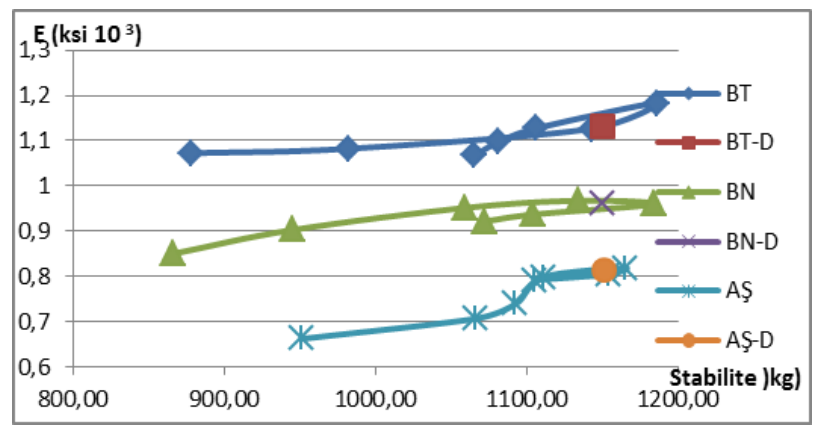

g) Dinamik Modül - Stabilite

\section{Şekil 9. Karışımların dinamik modül Marshall parameter ĕgrileri}

\section{Sonuçlar}

Aşınma, binder ve bitümlü temel karışımlarının Marshall dizayn verileriyle belirtilen sıcaklık ve frekensta tahmin modeliyle hesaplanan dinamik rijitlik nodüllerinden,

- Karışımlarda 19 mm elek üzerinde kalan malzemenin dinamik rijitlik modülünü artırdığından, trafik yükü ve sıcaklıktan en fazla etkilenenn aşınma tabakası karışımlarının kaplama konforuda dikkate alınarak maksimum dane boyutunun büyütülmesi

- Marshall dizaynından hesaplanan optimum bitümden sonraki bitüm artışlarının dinamik rijitlik modülünü azalttığ1

- Referans sicaklığına göre $25 \mathrm{~Hz}$ frekansta bitümlü temel binder ve binder,aşınma tabakalrının dinamik rijitlik modülleri arasında \%18 fark olduğu

- Aynı sicaklıkta frekans azaldıkca ve aynı frekansta sıcaklık yükseldiikce dinamik rijitlik modülüm azaldığı

- Sicaklıkların yükleme sürelerine göre dinamik rijitlik modolünü daha fazla etkilediği

- Marsahall stabilitesi ve akma degerlerinin deney sicaklıklarının, projenin sicaklık degerleri göz önüne alınarak belirlenmesi buna gore tabakaların izafi mukavemet katsayılarının hesaplanması gerektiği tespit edilmiştir.

\section{Kaynaklar}

[1] Kök Eda, “ Karayolu Havaalanı Üstyapı Tasarım Yöntemleri Karşılaştırılmazı ve Türkiye Uygulamaları" İTÜ Fen Bilimleri Enstitüsü Yüksek Lisans Tezi , 2-3, 2008,

[2] A.Stephen,P.Cross, "Determination of Dynamic Modulus Master Curves for Oklahoma HMA Mixtures" Oklahoma State University, Final Report, $5,(2007)$

[3] AASHTO, Mechanistic-Empirical Pavement Design Guide , 10-27, 2008,

[4] KGM, Esnek Üstyapılar Projelendirme Rehberi, Teknik Araştırmas Dairesi Üst Yap1 Şübesi Müdürlüğü, 5-99,2008

[5] Karayolları Genel Müdürlüğü Birim Fiyatları https://birimfiyat com/ (17.09.2019)

[6] A.Güngör, A.Saglık “ Mekanistik Amprik Üstyapı Tasarımında Esneklik Modülünün Şartnamelere Uygulanması" Gazi University 18 Publication ,47,2009

[7] A.Tunç, Esnek Kaplama Malzemeleri El Kitabı ,199201,2004

[8] K.Sarayoot,"Conparısıon Between Resilent Modülüs and Dinamic Modülüs of Western Australlan Hot Mix Asphalt Basaed on Fleixeble Pavement Design Prespectives" 26th ARRB Conference -Reseasch 
Driving Efficiency Sdney ,1-18, Sempozyumu (İATS'09), 1-4,2009

[9] R.Timothy,"Dynamic and Resilient Modulus of Mn/DOT Asphalt Mixtures "Department of Civil EngineeringUniversity of Minnesota Technical ReportDocumentation, 14,2003

[10] M Y.Huang Pavement Analysis and Design Second Edition ,307,2006

[11] Y.Xiao "Evaluation of Engineering Properties of Hot Mix Asphalt Concrete for the MechanisticEmpirical Pavement Design"Ph.D thesis. Florida State University ,20-41,2009

[12] S. Cross, "Development of a Flexible Pavement Database for Local Calibration of the MEPDG",Final Report - FHWA-OK-11-06 (2), 7-22,2011

[13] G.Garcia ,M. Thompson, "HMA Dynamic Modulu Predictive Models -A Review" Research Report FHWA-ICT-07-005 ,8-20,2007

[14] A.Enwuso, "Conparative Study of Asphalt Institute Witczak 1-40D Dynamic Moduli for Polythene Bag Modified HMA Concrete Using Predictive Models" International Journal of Innovative Science, Engineering \& Technology, Vol 3 Issue 5 IJISET, $46-48,2016$

[15] S.Avcı,",Esnek Üstyapı Tasarım Yöntemlerinin AASHTO 2002 İle AASHTO 1993 Yöntemlerinin Karşılaştırılması "İTÜ Fen Bilimleri Enstitüsü Yüksek Lisans Tezi 10-23,2006

[16] M.Robbins," Thesis Graduate ,An Imvest1gation Into Dynamic Modulus of Hot-Mix Asphalt AndIt's Contributing Factors"Graduate Faculty of Auburn University 17-21,2009

[17] S.Yousefdoost,B.Vuong,P.Armstrong and B,Sullivan" Evaluation of Dynamic Modulus Predictive Models for Typical Australian Asphalt Mixes" 15th AAPA International Flexible Pavements Conference, 3-7,2013

[18] N.Kuloğlu ,’Bittum ve Bittümlü Sicak Karışım Rijitliğine Etki Eden Parametreler" Turk J Engin Environ Sci 25 (2001), 61 -67 TÜBİTAK, 2001

[19] E.Sayın ,H.Tanyıldızı, “Bitümlü Sıçak Karışımların Riritliğinin Bulanık Mantık ile Bulunması" Gazi Üniv Müh Mim Fak Der J Fac Eng Arch Gazi Univ Cilt 21, No 4, 645-649, 2006. ,

[20] E.Özgan, M. Emiroğlu,A.Beycioğlu ， K.Yı1dız "Asfalt Beronunda Rijitliğin Belirlenmesi İçin Bir Yaklaşım”, 5 Uluslararası İleri Teknolojiler

[21] M.Yılmaz, B.V.Kök,"Sivas Divriği Çelik Cürufunun Bitümlü Sıcak Karışımlarda Kullanılabilirliliğgl” C Ü
Fen-Edebiyat Fakültesi Fen Bilimleri Dergisi Cilt 30 Say1 1 1-18,

[22] M.Alataş , A.Perviz A, Y.Doğan,” Bitümlü Sıcak Karışımlarda Kullanılan Agrega Cinsinin Kaplamanın Fiziksel Özelliklerine Etkisi” Frrat Üniv Fen veMüh Bil Der Science and Eng J of F rrat Univ 18 (1), 81-89,2006 Conference -

[23] G.Garcia ,M.Thompso,’HMA Dynamic Modulu Predictive Models-Temperature Relations" Research Report FHWA-ICT-07-006,2-65,2007 R.Timothy ,'Dynamic and Resilient Modulus of Mn/DOT Asphalt Mixtures "Department of Civil EngineeringUniversity of Minnesota Technical Report Documentation, 14,2003

[24] T.Bennert 2009 "Dynamic Modulus of Hot Mix Asphalt”FHWA-NJ-2009-011 Final Report,6081,2009

[25] Y.Jianhu,"Modification of Dynamic Modulus PredictiveModels for Asphalt Mixtures Containing Recycled Asphalt Shingles “ A thesis Submitted to the Graduate Faculty Iowa State University ,9-72,2012

[26] Y.Huanan , S.Shen,"An Investigation of Dynamıc Modulus And Flow Number Proporties of Asphalt Mixtures İn Washıngton Washıngton State "University Research Project Agreement No 709867 Final Report ,14-81,2012

[27] J.L.Hyun"Performance Evaluation of High Modulus Asphalt Mixtures for Long Llife Asphalt Pavements" Construction and Building Materials 21 (2007) 107910872007

[28] A.Sağlık,A.G.Güngör ,'Resilent Modulus Of Unbound and Bituminous Bound Road Materials" 5th Eurasphalt \& Eurobitume Congress, 5-9,2012

[29] J.Stempihar, "Resilient Modulus to Dynamic Modulus Relationship and Pavement Analysis with the Mechanistic-Empirical Pavement Design Guide" Research Report Arizona State University 2-6,2015

[30] S.Esfandiarpour ,"An evaluation of Pavement ME Design dynamic modulus prediction model for asphalt mixes containing RAP" The 2015 Conference of the Transportation Association of Canada 3-18,2015

[31] J.Myung ,J. Younghan,’Dynamic Complex Modulus Prediction of Non-Conventional Asphalt Mixes" 51st ASC Annual International Conference Proceedings 2-8,2015. 